\title{
The Eff ects of Consent Decrees on Local Legislative Immunity
}

\author{
J. Robert Robertson $\dagger$
}

... you assert your ancient Privilege, and if the Lawyers do not understand it, let them break it, at their perils . . . .1

In a representative form of government, the legislator is "the public voice;"' the legislator speaks for the people. At the local level in particular, this voice both initiates and pervades the deliberative process. Nonetheless, there are situations in which a local lawmaking body will partially sidestep this role when it agrees, through a consent decree, to legislate in a certain way. In such a situation, a federal judge may be in a position to issue a contempt order, including the threat of imprisonment, to a dissenting legislator who votes according to his or her perceived duty to the people but against the decree. In a country governed by the people through their representatives, ${ }^{3}$ judicial coercion of this kind raises serious questions.

These questions bear on the issue of legislative immunity. In United States $v$ Brewster, Chief Justice Burger contrasted the origins of this immunity in England with its development in the United States. He commented, "[t]here is nothing in our history, for example, comparable to the imprisonment of a Member of Parliament in the Tower without a hearing . . . ." Despite this assertion, England and America actually differ little on the issue of imprisonment of legislators. In both countries, legislators have long had strong safeguards in the law, dating back to the English re-

$\dagger$ B.A. 1977, Virginia Military Institute; J.D. Candidate 1990, The University of Chicago.

3 Anchitell Grey, ed, 3 Debates of the House of Commons: 1667-1694 at 209 (Becket \& De Hondt, 1769) ("Grey"), statement in 1675 by Mr. Powle during the House of Commons debate on an individual member's waiver of parliamentary privilege in the case of Shirley $v$ Fagg, 6 Howell's St Trials 1121 (House of Lords 1675).

2 Federalist 10 (Madison) in Benjamin Fletcher Wright, ed, The Federalist 129, 134 (Belknap/Harvard, 1961).

s James Dewitt Andrews, ed, 2 The Works of James Wilson at 8 (Callaghan, 1896), "The constitution of the United States ... rests solely ... on the great democratical principle of a representation of the people...."

4408 US 501, 508 (1972). 
forms of the seventeenth century. Prior to those reforms, the English struggle for parliamentary privilege abounds with examples of executive and judicial coercion of the legislative process. Acutely aware of these abuses, the founders of the new government of the United States guaranteed in the Constitution legislative privileges that were already protected by the common law. ${ }^{5}$ Likewise, federal and state common law, and in many cases the corresponding state constitutions, assured the right of free legislative process at other levels of government. But the privileges of municipal legislators have recently come into question as the involvement of federal government in local affairs has increased.

The imprisonment of members of Parliament mentioned by Chief Justice Burger is comparable to a penalty imposed in a modern-day case involving the city of Yonkers, New York. ${ }^{6}$ In 1980, the Justice Department filed a desegregation suit in the District Court for the Southern District of New York. The case alleged intentional racial segregation in housing and public schools by the City of Yonkers and the Yonkers Board of Education. ${ }^{7}$ Five years later, the district court found that the city and the board had deliberately segregated both housing and public schools, and, in 1986, it ordered significant relief. ${ }^{8}$ After losing its appeal, the city complied with the school desegregation remedy, ${ }^{9}$ but balked at the housing remedy order. ${ }^{10}$ This resistance ostensibly ended when the city council finally assented to a consent decree on January $28,1988 .^{11}$ As part of the decree, the city agreed to adopt implementing legislation that would include tax abatements, zoning changes, and a package of incentives for local development. ${ }^{12}$ The ensuing har-

S See text at notes 54-65.

- United States $v$ Yonkers Bd. of Educ., 624 F Supp 1276 (S D NY 1985), affd 837 F2d 1181 (2d Cir 1987), cert denied, 108 S Ct 2821 (1988). Contempt order appealed in United States $v$ City of Yonkers, 856 F2d 444 (2d Cir 1988); stay granted for councilmen in Spallone v United States, $109 \mathrm{~S} \mathrm{Ct} 14$ (1988); cert granted for councilmen in $109 \mathrm{~S}$ Ct 1337 (1989); cert denied for the city in Yonkers $v$ United States, 1989 US LEXIS 1214. The parties complied with the consent decree on September 10, 1988. Robert McFadden, Stepping Back From Fiscal and Political Crisis: What is Next for Yonkers?, NY Times 36 (Sept 11, 1988).

7624 F Supp at 1288.

8 United States $v$ Yonkers Bd. of Educ., 635 F Supp 1538 (S D NY 1986) (public school remedy); 635 F Supp 1577 (S D NY 1986) (housing remedy).

- McFadden, NY Times 36 (Sept 11, 1988) (cited in note 6).

10856 F2d at 448 (the city at first defaulted and later refused to comply). See $635 \mathrm{~F}$ Supp 1577 (Housing Remedy Order).

1856 F2d at 448; (the city council voted to accept the decree on January 27, 1988; the court entered judgment the following day).

12 Id at 449. 
mony did not last. The council not only failed to implement the required legislation, it voted against a resolution indicating "commitment to the implementation" of the consent judgment, the housing remedy order, and the long term plan order. ${ }^{13}$

On July 26, 1988, Judge Leonard Sand issued an order giving the city one final opportunity to comply with the previous housing remedy order. ${ }^{14}$ On August 2, after the city had failed to enact the requisite legislation, the judge found the city in contempt and fined it $\$ 100$ a day, doubling the amount for each day of noncompliance. ${ }^{15}$ In a controversial move, the judge also found four councilmen in contempt for failing to vote for the legislation promised by the consent decree and fined each of them $\$ 500$ for every day the legislation remained unadopted. ${ }^{16}$ Beginning on August 11, the court would then imprison the dissident councilmen until they voted for the legislation or the legislation was passed. ${ }^{17}$ Though not parties to the original suit, the councilmen found themselves in the predicament of either voting in the manner ordered by the court or going to prison. They continued to vote against the resolution, and the court found the city and the four councilmen in contempt. ${ }^{18}$

On appeal, the Second Circuit affirmed the lower court's contempt sanctions against the councilmen but modified the sanctions against the city. ${ }^{10}$ The court declined to rule on the question of legislative immunity, holding that the consent judgment committed the council to enact the legislation. ${ }^{20}$ Concerning the appeal of a councilman who had never voted to accept any of the court's orders, including the consent judgment, the court held that he too was committed by the consent judgment. ${ }^{21}$ The court emphatically stated, "Whatever the scope of local legislators' immunity, it does not insulate them from compliance with a consent judgment to which their city has agreed and which has been approved by their legislative body."22 On September 1, 1988, the Supreme Court, over vigorous dissent by Justices Marshall and Brennan, granted a

1s Id.

14 Id at 450 .

13 Id at $450-451$.

16 Id at $451-452$. One councilman was not immediately fined. He was allowed to find counsel and appear before the court on August 4, when he was also found in contempt. This finding was made "retroactive to August 2." Id at 452.

17 Id at 452.

1s Id at $451-452$.

19 The Second Circuit limited the fine against the city to $\$ 1$ million a day. Id at 460 .

20 Id at 457.

21 Id.

22 Id. 
stay of the sanctions against the councilmen pending the filing of the petitions for writs of certiorari. ${ }^{23}$ The coercive fines against the city continued to run, and on September 1, 1988, the Yonkers City Council finally agreed to enact the requisite legislation. ${ }^{24}$

The decision by Judge Sand to penalize the individual councilmen for contempt is the most troublesome aspect of the Yonkers case. Indeed, his action is comparable to the actions of the judges in the early English cases, which resulted in the creation of the right of free speech and debate in Parliament. ${ }^{25}$ The English executive and judicial actions that brought the members of Parliament into court and the federal judge's use of contempt in Yonkers both interfered with the free legislative process that ultimately is the right of the people and one of the foundations of republican government.

The American form of republican government has as its foundation popular sovereignty. ${ }^{26}$ The people speak through their chosen representatives. This infusion of the people's will into government can be true to its source only if the spokespersons of the people are unhindered in their speech, debate, and lawmaking. The sole purpose of legislative immunity is to protect this mechanism. If a legislator is deterred from faithful representation by other forces in government, the foundation of popular sovereignty and the legitimacy of the government are imperiled. The core value of legislative freedom, therefore, is the ability of representatives to voice the people's thoughts and consciences without any restriction. When the people of a national or local government choose a republican form of government, they expect that this core value will not be taken away from them without their consent. Conversely, a legislator who takes on the heavy burden of speaking and voting for the people-sometimes in the face of substantial pressure-must expect that the people will protect him or her from personal liability. Legislative immunity provides this protection.

This comment argues that a federal judge cannot use a consent decree to force a municipal legislator to vote in a prescribed way. The comment first reviews the history of legislative immunity in England and the United States and argues that the majority of

23 Spallone v United States, 109 S Ct 14 (1988), cert granted, 109 S Ct 1337 (1989).

${ }^{24}$ McFadden, NY Times 36 (Sept 11, 1988) (cited in note 6).

${ }^{28}$ Discussed in text at notes 30-50.

${ }^{28}$ For a good summary of this concept of republican government and the Framers' intent, see Comment, The Guarantee of Republican Government: Proposals for Judicial Review, 54 U Chi L Rev 208, 227-30 (1987). 
federal appeals courts is correct in extending the privilege to municipal legislators. This historical examination suggests that the privilege is public in nature, and necessary to the structure of representative government. Second, the comment explores whether individual legislators or the legislature as a whole may waive the privilege. After determining that the public nature of the right precludes such waiver, the comment concludes that a consent decree can have no effect upon the immunity.

\section{History of Legislative Immunity in England}

Article 9 of the English Bill of Rights guarantees free "speech or debate," ${ }^{27}$ a privilege proclaimed at the opening of each Parliament as an "ancient and undoubted right." This right manifests Parliament's independence from the Crown and judiciary, an independence secured after centuries of struggle. From its origins, legislative immunity was intended mainly as a protection of legislative independence, rather than a personal right protecting individual legislators from penalties. ${ }^{29} \mathrm{~A}$ brief survey of the history of the struggle for legislative independence will reveal the nature of the right and the way in which it protects such independence.

One of the earliest assertions of legislative immunity was made in the early sixteenth century by Richard Strode, a Member of the House of Commons, who was convicted and imprisoned for proposing legislation in Parliament. ${ }^{30}$ Strode appealed to the Parliament, which abruptly overturned his conviction and resolved in an act that its members had an absolute privilege "for any bill, speaking, reasoning, or declaring of any matter or matters concerning the Parliament."31 Although this act was designed to secure permanently Parliament's freedom from judicial intervention, such was not the result.

Well into the seventeenth century; the degree of parliamentary independence from executive and judicial coercion remained

271 William and Mary sess 2, c 2 (1689). See also Lois G. Schwoerer, The Declaration of Rights, 1689 at $81-87$ (Johns Hopkins, 1981).

28 This right of free speech and debate, though renowned as "ancient and undoubted," first appeared during the reign of Henry VIII. Schwoerer, The Declaration of Rights, 1689 at 81-82 (cited in note 27). See also William S. Holdsworth, 6 A History Of English Law at 97-99 (Little, Brown, 1924).

${ }^{20}$ Brewster, 408 US at 507.

${ }^{30}$ Barnett Cocks, ed, Erskine May's Treatise on The Law, Privileges Proceedings and Usage of Parliament at 49-50 (Butterworth, 17th ed 1964); 4 Henry 8 c 8 (1512).

s1 Cocks, ed, The Law, Privileges, Proceedings at 49-50. 
unsettled. ${ }^{32} \mathrm{Sir}$ John Eliot, a leading figure in seventeenth-century English politics, battled for legislative independence, ${ }^{33}$ only to be convicted and imprisoned for his trouble in 1629. Eliot had fought for the adoption of the Petition of Right in 1628 and in his final speech in the House of Commons had protested the imposition of "tonnage and poundage without grant of Parliament." 34 The Crown charged that the speech was "malicious," "seditious," and "of dangerous consequence." He was further accused of conspiring to confine the speaker of the House to his chair by force. ${ }^{35}$ The speaker had been ordered by the King to close the session, but Eliot and the other members not only refused the order to prorogue the Parliament, they compelled the speaker to allow Eliot to speak. $^{36}$ Nine were arrested of which six "eventually made their submission" and were released. ${ }^{37}$ The remaining three including Eliot were tried in the Court of King's Bench and all pleaded that "these offenses are supposed to be done in parliament, and ought not to be punished in this court, or in any other, but in parliament." 38 The court convicted them, holding that the Act in Strode's Case applied only to Strode and was not general law..$^{39}$ The unfortunate Eliot died in prison in 1632,40 a martyr for the cause of parliamentary independence. ${ }^{41}$

The cases against Strode and Eliot demonstrate that the evolution of legislative immunity resulted from Parliament's desire

${ }^{32}$ See Sir Walter Raleigh, The Prerogative of Parliaments in England: Proved in a Dialogue (pro \& contra) Between a Councellour of State and a Justice of the Peace (Middelburg, 1628). See also Christopher Hill, Intellectual Origins of the English Revolution at 204 (Oxford, 1965).

3s See generally Harold Hulme, The Life of Sir John Eliot 1592 to 1632: Struggle for Parliamentary Freedom (George Allen \& Unwin Ltd, 1957). Eliot was greatly influenced by Raleigh's execution and led the fight for the reversal of Raleigh's attainder. John Forster, 1 Sir John Eliot: a Biography 1592-1632 at 19-20 (Chapman and Hall, 2d ed 1872); Hill, Intellectual Origins at 208-09 (cited in note 32). Eliot began to use the words of Raleigh's The Prerogative of Parliaments as a source for his crusade for parliamentary independence in 1626. Id.

34 Hulme, The Life of Sir John Eliot at 226-64, 312.

ss Proceedings against Sir John Elliot, 3 Howell's St Trials at 293-294 (KB 1629).

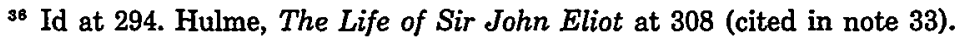

${ }^{37}$ Holdsworth, 6 A History Of English Law at 98 (cited in note 28).

${ }^{38} 3$ Howell's St Trials at 294. For a description of the proceedings and the fates of the other eight members, see Hulme, The Life of Sir John Eliot at 316-38 (cited in note 33).

39 3 Howell's St Trials at 294, 309-310.

10 Holdsworth, 6 A History Of English Law at 98 (cited in note 28).

11 "Sir John Eliot's fame ... rests on his defense of the liberties of the House of Commons, on his defense of freedom of speech for which he sacrificed his life." Hulme, The Life of Sir John Eliot at 390 (cited in note 33). "[T] he spirit of political liberty brought to life by the Petition of Right was immeasurably strengthened by the martyrdom of Eliot." Id at 391. 
to protect its independent legislative role. ${ }^{42}$ Whereas Eliot fashioned his plea around the assertion that the King's Bench had no jurisdiction over him, ${ }^{43}$ his ultimate objective was to defend the independence of the House of Commons. Eliot reveals the reason for his tenacious defense of the privilege of parliament in his allegorical Apologie for Socrates: "it was for fear of the public privilege and prejudice, not in jealousy of himself, that [he] exposed his fortune and his person to preserve the right of the Senate." 44 That he refused a trial and elected to languish in prison illustrates Eliot's stalwart belief in legislative immunity as a public right. Eliot's co-defendants, who were fined for conspiracy and sedition, also placed themselves in considerable jeopardy to protect the privilege of Parliament.45

Subsequent resolutions in Parliament leading to the creation of the speech or debate privilege realized Eliot's objective. ${ }^{46}$ Only nine years after his death, Parliament resolved that the charges against Eliot and the others "for matters done in parliament, [were] a breach of the privilege of parliament."47 In 1667, the House of Commons resolved that the Act in Strode's Case was general law and protected all members of Parliament "for and touching any bills, speaking, reasoning, or declaring of any ... matters, in and concerning the parliament." 48 The House further said that the privilege was both an "ancient and necessary" right."

42 United States v Brewster, 408 US 501, 507-508 (1972), citing United States v Johnson, 383 US 169, 178 (1966), and comparing the English to the American privilege.

43 3 Howell's St Trials 293, 293-294. The use of the jurisdictional plea to assert privilege simply may have had a firmer legal basis before the English Bill of Rights. Eliot's assertion of privilege overshadows any argument based on the relationship between courts. Later in the seventeenth century, when a member of the House of Commons was being charged in the House of Lords, the call for privilege was as strongly heard as it was when a court happened to be subordinate to the House; see 3 Grey 140-47 regarding Shirley v Fagg, 6 Howell's St Trials 1121 (House of Lords 1675). See also Stockdale v Hansard, 112 Eng Rpt 1112, 1154-55 (QB 1839).

"Sir John Eliot, Apologie for Socrates 15, reprinted in 3 Old South Leaflets No 59 (Directors of the Old South Work, 1896) (emphasis added).

45 Holdsworth, 6 A History Of English Law at 97-98 (cited in note 28).

'6 For an appendix detailing these various resolutions, see 3 Howell's St Trials at 312319.

47 Howell's St Trials at 312,315 . Holdsworth justifies the actions of the judges in Eliot's Case by pointing out that the charges of seditious speech were "mixed up with the charge of causing a riot in the House, which was not" privileged. Holdsworth, 6 A History of English Law at 269 \& $\mathrm{n} 4$ (cited in note 28).

68 3 Howell's St Trials at 314-315, "Upon a Report made by Mr. Vaughan from the committee concerning Freedom of Speech in parliament." See also Tenney $v$ Brandhove, 341 US 367, 372 (1951).

10 3 Howell's St Trials at 315. 
Finally, more than fifty years after Eliot's death, the 1689 Bill of Rights declared explicitly "[t] hat the Freedom of Speech, and Debates or Proceedings in Parliament, ought not to be impeached or questioned in any Court or Place out of Parliament."'\$o

The Framers of the U.S. Constitution were well acquainted with the injustice of these seventeenth-century English trials ${ }^{61}$ and with the struggle for parliamentary independence. ${ }^{52}$ The privilege of "[f]reedom of speech and action in the legislature was taken as a matter of course by those who severed the Colonies from the Crown and founded our Nation." ${ }^{33}$ When they wrote a constitution for their new government, they included the legislative right of speech or debate.

\section{SPEech oR Debate AND the U.S. Constitution}

They shall in all Cases, except Treason, Felony and Breach of the Peace, be privileged from Arrest during their Attendance at the Session of their respective Houses, and in going to and returning from the same; and for any Speech or Debate in either House, they shall not be questioned in any other Place. ${ }^{54}$

The privilege of legislative immunity is deeply embedded in our political system. The Articles of Confederation recognized the privilege of free speech or debate in the Congress as an essential right. ${ }^{55}$ The Framers of the Constitution clearly thought that such freedom was important to the structure of government: they placed the Speech or Debate Clause in the body of the Constitution, and, in contrast to their handling of most other "matters of importance," they "accepted [the clause] with unanimous consent and without discussion."

so 1 William and Mary sess 2, c 2, art 9; See also Tenney, 341 US at 372. For a summary of the effects of Eliot's pursuit of legislative freedom on English History, see Hulme, The Life of Sir John Eliot at 390-394 (cited in note 33).

s1 The Framers had access to Howell's State Trials and seemed to be well acquainted with its contents. See Peter Westen, The Compulsory Process Clause, 73 Mich L Rev 71, 94 (1974).

52 Tenney, 341 US at 372-373.

${ }^{83}$ Id at 372. See also Forrest McDonald, Novus Ordo Seclorum: The Intellectual Origins of the Constitution at 46 (U Kan, 1985), stating that the "same right was claimed by the American colonial legislatures throughout the eighteenth century."

s4 US Const, Art I, \& 6, cl 1.

Bs Arts of Confed, Art V. Justice Frankfurter commented on the similarity between the English Bill of Rights Article 9 and the Articles of Confederation Article V in Tenney, 341 US at 372 .

${ }^{s B}$ David K. Watson, 1 The Constitution of the United States: Its History, Application and Construction at 326 (Callaghan, 1910). See Max Farrand, ed, 2 The Records of the 
The right of legislative immunity appears not only in the U.S. Constitution, but also in the constitutions of most states. ${ }^{57}$ The state constitutions of Vermont and Massachusetts contain typical clauses: "The freedom of deliberation, speech and debate in the legislature, is so essential to the rights of the people, that it cannot be the foundation of any accusation or prosecution, action or complaint, in any other court or place whatsoever." cepted in the common law moreover that legislators are not liable for their legislative acts. ${ }^{59}$

Such universal acknowledgement of the privilege reflects a century-old common law tradition in this country. The Framers merely gave it a permanent place in the structure of the new government. This universal acceptance of the privilege was closely tied to a commitment to the separation of powers. The necessity of separation of powers in a free society was most strongly advocated by Montesquieu, who was, of course, a major influence on many of the Framers. ${ }^{60}$ Montesquieu thought that a confusion of powers could lead to "arbitrary control" or "oppression." If the "judiciary power be not separated from the legislative and executive," "there is no liberty." many English writers had also developed ideas of separate powers. ${ }^{63}$

The principle of speech and debate is an integral part of such

Federal Convention of 1787 at 254 (Yale, 2d ed 1937). See also United States $v$ Johnson, 383 US 169, 177-178 (1966).

${ }^{87}$ Forty-three state constitutions contain the speech or debate privilege; five state constitutions have a more restricted form of immunity; "[o]nly Florida and North Carolina do not have some form of constitutional protection for legislators." Developments in the LawPrivileged Communications, 98 Harv L Rev 1450, 1615 n 129 (1985) (citations omitted).

ss Vt Const, ch 1, sec XVI (1786) (superseded 1793); Mass Declaration of Rights, Art XXI (1780) (emphasis added).

so See Tenney v Brandhove, 341 US 367, 373-376 (1951). See also Eugene McQuillin, 4 The Law of Municipal Corporations $\$ 12.222$ at 238-240 (Callaghan, 3d ed 1985), for a summary of state application of the immunity to local legislators. The treatise states that legislative immunity is "so elementary, so fundamentally sound, and has been so universally accepted, that but few cases can be found where the doctrine has been questioned and judicially declared." Id at 238-239.

0 See, for example, Federalist 9 (Hamilton) in The Federalist at 124, 126-29, and Federalist 47 (Madison) in The Federalist at 336, 338 (cited in note 2).

22 Baron de Montesquieu, 1 The Spirit of the Laws at 182 (Appleton, Thomas Nugent, trans, 1900).

2 Id.

4s Clement Walker, Relations and Observations, Historicall and Politick Upon the Parliament Begun Anno Dom. 1640 (1648); Marchamont Nedham, The Excellencie of a Free State (1656); John Locke, Second Treatise \$§ 143, 144, 150, 159 (1689); all reprinted in Philip B. Kurland and Ralph Lerner, eds, 1 The Founders' Constitution: Major Themes at 314-316 (Chicago, 1987). 
separation. ${ }^{64}$ By cloaking legislators in this privilege, the Framers assured that the people's representatives would be insulated from the coercion of other branches. Thomas Jefferson ably explained the goals served by such insulation:

[T] hat in order to give to the will of the people the influence it ought to have, and the information which may enable them to exercise it usefully, it was a part of the common law, adopted as the law of this land, that their representatives, in the discharge of their functions, should be free from the cognizance or coercion of the coordinate branches, Judiciary and Executive. ${ }^{68}$

Two different but complementary goals are evident from Jefferson's statement. First, the people must be free to control their representatives and their deliberations. Jefferson's notion that elected representatives "ought" to exert the "will of the people" is inexorably linked to the proposition that the speech and debate of legislators must be free of "coercion." Other branches of government cannot intrude on a legislator's freedom to vote without injuring the source of the representative's voice-the people.

Second, the people must have the necessary information to control the legislative process. If other branches may coerce the legislative branch, the people will be thwarted in their attempts to fix accountability on their rulers. The Framers' attitude towards accountability and its relation to the separation of powers can be seen in the struggle over the appointment and removal powers. In 1789, James Madison urged the Congress to limit the power to remove executive officers to the President. Arguing that any further confusion of the executive and the legislative branches would "abolish at once that great principle of unity and responsibility of the [E]xecutive department,"

64 See Johnson, 383 US at 178-179, in which the Court states that, "In the American governmental structure the clause serves the additional function of reinforcing the separation of powers so deliberately established by the Founders." Referring to Federalist 48 (Madison), the Court further states, "The legislative privilege, protecting against possible prosecution by an unfriendly executive and conviction by a hostile judiciary, is one manifestation of the 'practical security' for ensuring the independence of the legislature." See also Coffin $v$ Coffin, 4 Mass 1, 27 (1808); Federalist 66 (Hamilton) in The Federalist at 431, 435 (cited in note 2), "The truth is, that [even in cases of possibly harmful legislation] . . . it is essential to the freedom and to the necessary independence of the deliberations of the body, that the members of it should be exempt from punishment for acts done in a collective capacity ...."

Bs United States $v$ Brewster, 408 US 501, 548-549 (1972) (Brennan, dissenting and citing Paul Ford, ed, 8 The Works of Thomas Jefferson at 322 (Putnam, 1904)).

Bs I Annals of Cong 518. See also Bowsher $v$ Synar, 478 US 714, 723 (1986) (discussing 
principle is more clearly laid down in the [C]onstitution than that of responsibility."

Alexander Hamilton had earlier used the same argument to justify the appointment process. He stated: "The blame of a bad nomination would fall upon the President singly and absolutely. The censure of rejecting a good one would lie entirely at the door of the Senate . ..."68 The separation of powers, therefore, "secure[s] the accountability of the individuals in the great departments of the government.".68 Legislative immunity from coercion by other branches is an important component of this doctrine: it both allows the voice of the people to be heard, and it helps ensure actual separation.

The denial of legislative immunity could destroy accountability by allowing courts to interfere with legislation before it is enacted. Judicial review of a law after it is passed, on the other hand, protects both separation and the underlying value that legislative immunity is meant to protect-free deliberation and accountability. When the judiciary declares a law invalid, it fixes accountability on the judge for his or her review and on the legislature for its mistake. The people then have no doubt who is responsible. If legislators are not immune, however, they can be coerced to legislate in a manner that may be at odds with the will of the people. When this happens the people not only lose their representation in the legislative process, but also are less clearly able to fix accountability on the de facto legislator, who may well be a judge acting through a consent decree. A judge's encroachment into legislative affairs is thus undesirable, since it precludes the "full, vigorous, and open debate" that the separation of powers doctrine "deliberately" preserves. ${ }^{70}$

Although state or local legislative immunity does not support the separation of powers in the federal government, it protects the same values of free deliberation and accountability. Moreover, it helps to preserve a state or local version of the separation of powers. On the federal level, the Speech and Debate Clause protects popular sovereignty from judicial and executive attacks by ensur-

the debate over the removal power).

${ }^{67} 1$ Annals of Cong at 480.

${ }^{83}$ Federalist 77 (Hamilton) in The Federalist at 484, 486 (cited in note 2). For a discussion of responsibility and appointments at the Constitutional Convention, see Farrand, 2 Records at 41-43, 80 (cited in note 56).

69 Nathaniel Chipman, Sketches of the Principles of Government 120-127 (1793), reprinted in Kurland and Lerner, eds, 1 The Founders' Constitution at 333 (cited in note 63).

${ }^{70}$ Bowsher, 478 US at 722. 
ing that representatives execute their offices without impediment. Legislative immunity at the state and local level works in a similar way by protecting state and local legislators from coercion by the federal government and from coercion by competing branches at the local level. On the federal level, the Speech and Debate Clause allows the people to fix responsibility upon the legislature for legislative acts. Congressmen and Senators cannot place the blame for their actions on others; they have full independence to vote as they please. In the same way, legislative immunity ensures accountability at the local level. State and local legislators may not blame the courts or Congress for their actions.

\section{Legislative Immunity Under the Federal Common Law}

This comment has thus far detailed how the policies and history underlying the federal guarantee of legislative immunity apply to legislative immunity at the local level. Yet, the Speech and Debate Clause of the federal Constitution does not apply to state and local legislators. We must therefore turn to other sources in order to find the legal basis of this immunity.

\section{A. The Scope of Federal Common Law Immunity}

The Supreme Court has found protection for legislative bodies in federal common law. In Tenney $v$ Brandhove, the Court compared the Speech or Debate Clause, which protects members of Congress, to the common law immunity of others who act in "the sphere of legitimate legislative activity." Hi Here the Court held that individual members of the California legislature, who had been sued by the plaintiff for a deprivation of his rights under federal law, possessed legislative immunity. ${ }^{72}$ The Court refused to decide whether Congress had the power to abrogate that immunity. ${ }^{73}$ Instead, it held that, in passing 42 USC $\S \S 1983$ and 1985 (then 8 USC $\S \S 43$ and 47 ), Congress did not intend to abrogate that immunity. ${ }^{74}$ Justice Frankfurter, writing for the majority, explained that the roots of both the common law immunity and the constitutional privilege stem from the same historical foundation in the

71341 US at 376.

72 Id at $371,379$.

73 Justice Frankfurter seemed to doubt that Congress could abrogate such immunity: "Let us assume, merely for the moment, that Congress has constitutional power to limit the freedom of State legislators within their traditional sphere. That would be a big assumption." Tenney, 341 US at 376.

$"$ Id. 
"Parliamentary struggles of the Sixteenth and Seventeenth Centuries." $75 \mathrm{He}$ cited the English Bill of Rights as the last step in the establishment of the immunity that had been denied Sir John Eliot.78

In Lake Country Estates, Inc. v Tahoe Regional Planning Agency, ${ }^{77}$ the Supreme Court extended immunity beyond the state level to regional legislative bodies. Lake Country Estates involved a commission created by California and Nevada to oversee coordinate development in the Lake Tahoe area. In his dissent from the Court's opinion, Justice Marshall stated, "the majority's reasoning in this case leaves little room to argue that municipal legislators stand on a different footing than their regional counterparts." $\mathrm{He}$ argued that the majority's rule "applies with equal force whether the officials occupy local or regional positions."78 Following the Court's reasoning in this case, seven circuits have held that legislative immunity applies at the municipal level. ${ }^{99}$ The Eighth Circuit noted that there was not "a material distinction between the need for insulating legislative decision-making at the state or regional level and a corresponding need at the municipal level." 80 The same importance that state legislators have and that the Congress has under the Constitution gives local legislators protection under the common law.

\section{B. Immunity for Harmful Legislative Acts}

Legislative immunity under federal common law is absolute in character and broad in scope. It applies even when legislators violate the Constitution or commit a tort in the course of passing laws. In Tenney $v$ Brandhove, Justice Frankfurter reviewed the long history of legislative immunity and concluded that the privilege can be claimed even when it is used for an "unworthy purpose."81 His broad definition of immunity stems from its nature as

${ }^{70}$ Tenney, $341 \mathrm{US}$ at 372.

36 Id.

77440 US $391,405-406$ (1979).

78 Id at $407-408$.

79 See Yonkers, 856 F2d at 456, for a list of these cases.

so Gorman Towers, Inc. v Bogoslavsky, 626 F2d 607, 612 (8th Cir 1980). See Domestic Linen Supply \& Laundry Co. v Stone, 111 Mich App 827, 314 NW2d 773, 777 (Mich App 1982) (holding that a mayor and purchasing director were absolutely immune for statements made during a city council meeting). Michigan's common law protected municipal legislators's speech as early as 1893. Id. See also Timber Properties, Inc. $v$ Chester Tp., 205 NJ Super 273, 500 A2d 757, 763, 765-766 (NJ Super 1984) (holding that municipal officers have absolute immunity for legislative acts under both federal and state common law).

๑1 341 US 367, 377 (1951). 
a protection of the "public good," not as a "private indulgence."82 In cases in which private parties are harmed by legislative acts, the dispositive issue on liability is whether the defendant committed the offense while "acting as a representative." legislative immunity not only in cases where legislative acts incidentally harmed private parties (for example, through zoning changes ${ }^{84}$ ) but also in cases of more egregious conduct, such as voting to violate the civil rights of property owners, ${ }^{85}$ to drive a person out of business, ${ }^{86}$ to wrongfully discharge an employee, ${ }^{87}$ or to prevent a developer, for racially discriminatory reasons, from building housing for elderly and handicapped persons. ${ }^{\mathbf{8 8}}$

Such broad immunity might seem to work harshly against injured plaintiffs, but there are alternative remedies. The Supreme Court has noted that plaintiffs in such cases still have recourse against the city. In Owen $v$ City of Independence, the Court explained that when Congress enacted 42 USC $\$ 1983$ it allowed suits against cities, and yet retained the common law immunities for individual officers of government. ${ }^{89}$ Since the plaintiff's rights could be "vindicat[ed]" in this way, the Court "concluded that overriding considerations of public policy" required that certain government officials be immune from suit."

These "overriding considerations," which protect the "public good," are "equally applicable to federal, state, and regional legislators" $"$ and ought to apply to the protection of municipal legislators as well. A plaintiff may obtain a judgment against a city, while at the same time the immunity of individual legislators protects the interests of the people. ${ }^{22}$

${ }^{32}$ Id.

8s Coffin, 4 Mass at 29. In Kilbourn v Thompson, 103 US 168, 204-205 (1880), Justice Miller postulated that there might be some acts, such as executing a "Chief Magistrate of the nation" or "assuming the function of a court for capital punishment" that would be "such an utter perversion of their powers to a criminal purpose" that they should not be protected.

84 Hernandez $v$ City of Lafayette, 643 F2d 1188, 1194 (5th Cir 1981) (mayor has absolute immunity from suit for vetoing a zoning ordinance); Kuzinich v County of Santa Clara, 689 F2d 1345, 1349 (9th Cir 1982) (local legislators immune for general zoning ordinance).

${ }^{85}$ Reed v Village of Shorewood, 704 F2d 943, 952-953 (7th Cir 1983). The municipality, however, was held liable under § 1983.

${ }^{86}$ Espanola Way Corp. v Meyerson, 690 F2d 827 (11th Cir 1982).

${ }^{87}$ Aitchison $v$ Raffiani, 708 F2d 96 (3d Cir 1983).

88 Gorman Towers, 626 F2d at 610.

so Owen v City of Independence, 445 US 622, $653 \mathrm{n} 37$ (1980).

${ }^{20}$ Id at 653 \& $n 37$.

92 Lake Country Estates, 440 US at 405.

${ }^{92}$ Gorman Towers, 626 F2d at 612-13. The legislative history of $\S 1983$ supports the 
It might seem unjust that retention of the privilege might allow "reckless men to slander and even destroy others." whose constitutional rights are infringed by the legislative acts of a city council may have a remedy against the city, but the remedy might not be fully adequate in every case. Nonetheless, "[t]he injury to the reputation of a private citizen is of less importance... than the free and unreserved exercise of the duties of a representative, unawed by the fear of legal prosecutions." free society the "private benefit must submit to the public good."9s

The distinction between individual immunity and immunity for the municipality as a whole may seem illusory. Why should it matter whether a court enforces a consent decree against an individual legislator or against a governmental body? In both cases legislation may inevitably be passed, and in both cases the legislator may be pressured to enact specific legislation. The distinction is clear, however, when the force is exerted directly on the body and not on the legislator. In this instance, the representative still has some room to deliberate and hence may decide one way or another. This individual freedom to speak, debate, and choose is the core value that the immunity is meant to preserve. As the people's representative, he or she may even choose a course that causes the people to suffer, but the legislator remains accountable to the people. Further, holding the city but not individual legislators liable places the burden of correcting the conduct on the people, who are responsible for the acts of their representatives. Thus, some courts have enforced judgments that pressure the people to cause legislation to occur, and yet these decisions do not hold individual legislators liable and therefore do not cross the barrier of legislative immunity. ${ }^{96}$

intention of Congress to abrogate Eleventh Amendment immunity in order to allow suits against a state or municipality. Owen, 445 US at 638. Nevertheless, there is no evidence that Congress intended to abrogate absolute legislative immunity. Consumers Union, 446 US at 732-33. "[D]ifferent considerations" require that immunity be maintained for individual legislators. Id at $653 \mathrm{n} 37$.

${ }^{23}$ Brewster, 408 US at 516.

24 Coffin, 4 Mass at 28.

${ }^{25}$ Id.

98 United States $v$ City of Parma, Ohio, 661 F2d 562, 577 (6th Cir 1981) (required the city to "adopt a plan to utilize an existing" federal program). Arthur v Nyquist, 547 F Supp 468, 484 (W D NY 1982) (court directed "the Mayor and the Common Council to make available to the board an additional $\$ 7,400,000 "$ "), aff'd 712 F2d 809 (2d Cir 1983). 


\section{Damages and Prospective Relief}

The discussion thus far has focused upon retroactive damage relief, relief for acts done in the past. Unlike the typical cases for damages against legislators, the Yonkers case resulted in prospective relief. ${ }^{97}$ Immunity might be applied differently to prospective relief than to damages liability if the immunity were merely an individual right. The Second Circuit may have subscribed to this interpretation when it stated that the Yonkers councilmen could avoid personal jeopardy simply by resigning. ${ }^{98}$ Prospective relief, therefore, does not pose as great a danger to the legislator, since he or she can step aside or comply and not face a penalty. Nevertheless, since legislative immunity has the main purpose to protect deliberation and choice in legislative activity-not the individual-the type of relief sought against a legislator is unimportant. If the immunity was meant to protect a councilman as an individual only, resignation might be a satisfactory choice. In seventeenthcentury England, for example, Eliot might have chosen to obey the king's command to prorogue the session. Indeed, had Eliot not delivered his speech in defiance of the order, he would have avoided imprisonment. Similarly, the state supreme court justices in Supreme Court of Virginia $v$ Consumers Union might have resigned to avoid the declaratory action brought against them under $\$ 1983$. And yet, the U.S. Supreme Court held that in their legislative role (as promulgators of the bar code) the justices were immune from the award of attorney's fees that would have accompanied any prospective relief. ${ }^{98}$ The "public privilege"100 of a free legislative process, not the individual's protection from suit, is the core value of the immunity. It should apply to any person performing the legislative function regardless of the form of relief sought.

\section{Legislative and Executive Acts}

Legislative immunity is based not on a legislator's title, but on the nature of his or her action. ${ }^{101}$ It is necessary, therefore, to dif-

92 The Supreme Court has held that those performing legislative acts at the state level are immune from both retroactive and prospective relief. Supreme Court of Virginia $v$ Consumers Union, 446 US 719, 732-733 (1980) (holding that the justices of the state supreme court were immune from liability for attorney's fees and prospective relief for the legislative act of promulgating the state bar code).

${ }^{98}$ United States $v$ City of Yonkers, 856 F2d 444, 457 (2d Cir 1988).

946 US at 738.

100 Eliot, Apologie for Socrates at 15 (cited in note 44).

101 Consumers Union, 446 US at 734. 
ferentiate carefully between legislative and executive acts, ${ }^{102}$ since in certain cases, a municipal legislator can perform an executive act that does not fall within absolute protection. A local legislator has absolute immunity for "every thing said or done by him, as a representative, in the exercise of the functions of that office."103 The "formulation of policy"104 and the "drafting" of ordinances are legislative. In short, legislative immunity protects legislators for acts that are "clearly a part of the legislative process."106 Executive acts, on the other hand, have only qualified immunity. ${ }^{107}$ The representative character of legislating distinguishes the two and requires greater protection for legislative acts. Limitation of the immunity for executive acts is required because the beneficial check of judicial review would be ineffective if an official could not be prevented from or punished for executing judicially invalidated laws.

A definitional problem arises when executive and legislative powers are combined in the same body. Justice Marshall hesitated to grant certiorari in Yonkers because of the dual nature of the Yonkers city council, which exercised both "executive and legislative powers."108 Of course, not even the federal system has complete separation of powers. ${ }^{108}$ When the Court has encountered the mixed nature of some state offices in the past, it has consistently characterized the act of legislating as pertaining only to the nature of the activity and not to the title of the person performing the function. ${ }^{110}$ Indeed, both the Yonkers city council and Judge Sand seemed aware of this, and each wanted the other to carry out the essentially legislative function of approving the policy of the hous-

102 Compare Aitchison v Raffiani, 708 F2d 96, 99 (3d Cir 1983) (mayor immune for voting to abolish a person's government job; borough attorney immune for drafting the legislation), with Gross $v$ Winter, 692 F Supp 1420, 1424-1425 (D DC 1988) (councilwoman not immune for discharging an employee, because the action was not done by the council as a part of "enacting legislation."). See also Cinevision Corp. $v$ City of Burbank, 745 F2d 560, 580 (9th $\mathrm{Cir} 1984$ ) (holding that voting on proposed concerts is an executive function, since it was merely "monitoring and administering the contract" and was "more the type of ad hoc decisionmaking engaged in by an executive.").

${ }^{103}$ Coffin, 4 Mass at 27.

104 Cinevision, 745 F2d at 580; Breck v Ulmer, 745 P2d 66, 71 (Alaska 1987).

${ }^{105}$ Aitchison, $708 \mathrm{~F} 2 \mathrm{~d}$ at 99.

${ }^{108}$ Brewster, 408 US at 516. In $\S 1983$ actions, the Court "generally ha[s] equated" the legislative immunity of the Speech or Debate Clause to the privilege in the common law. Consumers Union, 446 US at 733.

${ }^{107}$ Scheuer v Rhodes, 416 US 232, 243-248 (1974).

${ }^{108}$ Spallone $v$ United States, 109 S Ct 14, 19 (1988).

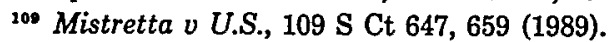

110 Consumers Union, 446 US at 734. 
ing plan. ${ }^{111}$ Judges usually try to leave this lawmaking to the legislators in order to avoid constitutional and public accountability problems. Consent decrees, since they emanate from an agreement by the parties, can relieve a judge of the task of forcing action. If the decree contains an agreement to legislate and the legislators fail to comply, however, the judge may interfere with the legislative process by ordering compliance.

Since the nation's founding, legislative freedom has been protected by the U.S. Constitution, the various state constitutions, and the common law. This freedom is traceable to the founding itself and, before that, to the English people's assertion of their sovereignty in government in the seventeenth century. The Speech or Debate Clause protects this freedom in Congress, the state constitutions secure it in state government, and the common law guards it at all other levels. When a court suppresses the freedom of speech or debate of local legislators, the federal common law may be the last line of defense. This defense is warranted, since the right of the people to representation extends through all levels of the hierarchy of government-municipal, state, and federal. A municipal legislator's voice may seem insignificant in the grand scheme of lawmaking, but it is still the voice of the people. Legislative immunity ensures the unimpeded deliberation and lawmaking functions of the people through their representatives and is an essential ingredient in the republican form of government.

The histories of our political system and common law reveal that the roots of legislative immunity are deep. The people possess this freedom just as they possess the right to choose their government. Those who are elected to represent the people likewise have a vested right in the privilege; they should not be held liable for representing their constituents' will.

\section{The Abrogation and Waiver of Legislative Immunity}

Thus far, this comment has argued that it is proper to extend the absolute immunity traditionally accorded state legislators to municipalities as well. As noted, seven courts of appeal have held that immunity exists on the municipal level, although the Supreme

111 United States $v$ City of Yonkers, 856 F2d 444, 450-451 (2d Cir 1988). The city had even tried to avoid the responsibility of performing the legislative function by returning the $\$ 30$ million in federal funds. Id at 449 . 
Court has not specifically addressed such legislative immunity. ${ }^{112}$

Nevertheless, the existence of such immunity does not end the inquiry. The issue remains whether legislative immunity be waived either by local legislative bodies, or by individual legislators. If either sort of waiver is possible, then legislators may be bound to vote in a certain way via consent decrees. The answer to this question depends chiefly on whether the right of immunity is a private right, or a public one. If the right is purely private, then each legislator would have to waive the privilege individually in order to be subject to sanctions. As the early English cases and the development of the right in America suggest, legislative immunity has, as its main purpose, the "preserv[ation of] legislative independence,"11s and is a "public privilege."114 The judiciary, therefore, must protect this independence "without altering the historic balance of the three co-equal branches of Government."115 Any question of waiver must focus on the nature of this right and the values it is meant to protect. The following two sections examine whether Congress has abrogated the immunity of local legislators and whether or not such immunity is waivable.

\section{A. Has Congress Abrogated the Immunity of Local Legislators?}

In determining whether Congress abrogated immunity, both its intent and its power to do so must be examined. Regarding intent, the Supreme Court has been reluctant to find a waiver. In Tenney, the Court found it inconceivable "that Congress-itself a staunch advocate of legislative freedom-would impinge on a tradition so well grounded in history and reason . . .."116 The Court held that, in passing the "statute of 1871" (which later became 42 USC § 1983), Congress did not intend that the common law immunity of legislators be abrogated. ${ }^{117}$

Regardless of whether Congress has intended to abrogate immunity, it seems unlikely that Congress has the power to abrogate legislative immunity for municipal councilmen. ${ }^{118}$ Objections to

112 See text accompanying notes 77-80.

11 Brewster, 408 US at 508.

114 Eliot, Apologie for Socrates at 15 (cited in note 44).

115 Brewster, 408 US at 508.

116 Tenney, $341 \mathrm{US}$ at 376.

${ }^{117}$ Id at 379. See Consumers Union, 446 US at 732, 738, which held that "Congress did not intend § 1983 to abrogate" the legislative immunity of state legislators or those acting in the capacity as such for either damages or prospective relief (citing Tenney, 341 US 367 (1951)). See also note 92.

118 In Tenney, 341 US at 376, the Court cautioned that it would be a "big assumption" 
Congress's power can be made on two grounds: the First Amendment freedom of speech, and the federal government's duty to guarantee republican government to every state.

A few legislators have pleaded that Congress is restrained in its power to abrogate legislative immunity at any level because the "speech or debate" of legislators is protected as "free speech" under the First Amendment. The Second Circuit rejected this claim in Yonkers. ${ }^{119}$ However, other courts have accepted the application of the First Amendment to a legislator's act of voting. ${ }^{120}$ This comparison of the legislative privilege of unhampered voting to free speech may in fact be tenable, because originally "freedom of speech" referred only to the legislative privilege. ${ }^{121}$ It seems anomalous that the citizen's right to petition government and to speak on political issues should stop at the council chamber door. The analogy of voting to political speech does highlight the public nature of legislative immunity and the core value that it reflects-a representative form of government.

Abrogation of immunity may also interfere with the government's duty to guarantee a "Republican Form of Government" to every state. ${ }^{122}$ The Constitution seems to restrict the federal government's power to take away legislative immunity from a subordinate legislature. ${ }^{123} \mathrm{By}$ abrogating the immunity of legisla-

to think that Congress had the power to "limit the freedom of State legislators."

118 Yonkers, $856 \mathrm{~F} 2 \mathrm{~d}$ at 457.

${ }^{120}$ See Wrzeski $v$ City of Madison, 558 F Supp 664 (W D Wis 1983) (holding that the First Amendment protected a city councilwoman from an ordinance imposing penalties on her for refusing to vote). See also Clarke $v$ United States, 705 F Supp 605 (D DC 1988) (holding that a Congressional act violated the First Amendment because it compelled the District's councilmen to vote for an amendment to a city act). The court held that the act of voting was "core political speech." Id at 610, citing Buckley $v$ Valeo, 424 US 1, 14 (1976). But note that unlike Yonkers, the alleged coercion in Clarke did not affect any individual's immunity; the act, which threatened a reduction in federal funds, was addressed to the city as a whole.

${ }^{122}$ McDonald, Novus Ordo Seclorum at 46 (cited in note 53).

122 US Const, Art IV, § 4. Note that the Supreme Court has hesitated on questions regarding the forms of state governments on the ground that such "political question[s]" are "nonjusticiable." See Baker v Carr, 369 US 186, 224-29 (1962).

${ }_{123}$ Madison defines a republic as "a government in which the scheme of representation takes place" and through that representation the "public voice" may "be more consonant to the public good than if pronounced by the people themselves ...." Madison's understanding of a republican form of government is not dependent on whether the government is at the local or federal level. Federalist 10 (Madison) in The Federalist at 129, 133-35 (cited in note 2). Hamilton declares that the Judiciary "can declare the acts of [the legislature] void." The premise that the "interpretation of the laws is the proper and peculiar province of the courts" does not seem to require or indicate that the judiciary has the power to coerce individual legislators to vote in a prescribed manner. Federalist 78 (Hamilton) in id at 489, 492. 
tors, Congress or the courts affect the form and operation of a legislative body, and alter the independence of a subordinate branch of state government. If a government's representative branch does not have the freedom to vote in a representative manner, it is not a republican form of government.

B. Can Either an Individual Legislator or a Legislative Body Waive the Public Privilege?

The history of legislative immunity reveals that it is not merely a private right, waivable by the individual. It is a public right, for the benefit of the people as a whole. The Supreme Court has never decided whether a legislative body or individual legislature may waive the privilege. In United States $v$ Helstoski, ${ }^{124}$ the Supreme Court held that in the absence of a waiver, which is "at least as clear and unambiguous" as a waiver of Fifth Amendment protection, evidence from a congressman's legislative actions could not be used against him in a criminal prosecution. ${ }^{125}$ Although the Court questioned whether any waiver is constitutional, it did not decide the issue since there was no "explicit and unequivocal expression" of a waiver in the case. ${ }^{126}$ Since the question has been left open by the courts, it is necessary to turn to history.

In his Manual Of Parliamentary Practice, Thomas Jefferson describes legislative immunity as a privilege of the House as a whole. A member who waives it individually can be punished for such an attempt and in any case "cannot in effect waive the privilege of the House." ${ }^{227}$ Jefferson cites the case of Sir John Fagg, a member of the House of Commons, who had waived the privilege in a case appealed to the House of Lords. ${ }^{128}$ Fagg was sent to the Tower for his indiscretion ${ }^{129}$ because the House believed that no argument justified an individual's waiver of privilege. ${ }^{130}$ Under Jef-

124442 US 477 (1979).

${ }^{125}$ Helstoski, 442 US at 492-93.

${ }^{126}$ Id at 493 . "We recognize that an argument can be made from precedent and history that Congress, as a body, should not be free to strip individual Members of the protection guaranteed by the Clause .... The controversy over the Alien and Sedition Acts reminds us how one political party in control of both the Legislative and the Executive Branches sought to use the courts to destroy political opponents." Id at 492-93.

127 Thomas Jefferson, A Manual Of Parliamentary Practice, for use of the Senate of the United States, reprinted in Joel B. Sutherland, A Congressional Manual 103, 119 (Peter Hay, 1839).

${ }^{128}$ Id, citing 3 Grey at 140, 222 (cited in note 1). See Shirley v Fagg, 6 Howell's St Trials 1121 (House of Lords 1675).

${ }^{120} 3$ Grey at 226 (cited in note 1).

230 Id at 140. The dispute over the privileges of the House of Commons temporarily 
ferson's view, a municipal legislator's waiver of his or her privilege, is not a valid waiver because it is without authority.

Jefferson's statement should not be taken to mean that the House as a whole can waive the privilege, for legislative immunity is more than a mere privilege of the legislature. It is integral to the structure of government and is designed for the benefit of the public as a whole. This concept-that the purpose of the immunity is to protect the public good-is a constant theme in cases involving legislative immunity from seventeenth century England to present day America. In the leading English case of Stockdale $v$ Hansard, Justice Coleridge, after deciding that a publisher could not gain legislative privilege for a libellous work simply by allowing Parliament to publish it, stated: "The privileges of the House are my own privileges, the privileges of every citizen in the land."131

The privilege has been regarded as a public right in America as well. James Wilson, a Framer who championed the addition of the Speech or Debate Clause to the Constitution, described the purpose of the privilege:

In order to enable and encourage a representative of the public to discharge his public trust with firmness and success, it is indispensably necessary, that he should enjoy the fullest liberty of speech, and that he should be protected from the resentment of every one, however powerful, to whom the exercise of that liberty may occasion offence. ${ }^{132}$

In the early nineteenth century case of Coffin $v$ Coffin, ${ }^{133}$ Chief Justice Parsons of the Massachusetts Supreme Court described legislative immunity as an individual privilege, a privilege of the House, and a public right. Not only can an individual not waive it, but since it is a legislator's privilege, the House as a whole cannot waive it. ${ }^{134}$ Ultimately, it is the people's right: the people grant this privilege to their individual legislators not to protect the elected officials, but to "support the rights of the people, by enabling their representatives to execute the functions of their office without fear of prosecutions, civil or criminal."135

This expression of the public nature of the legislative privilege

ended on November 22, 1675, when the Parliament was prorogued at the request of the Lords. 6 Howell's St Trials 1186 (House of Lords 1675).

131 Eng Rpt 1112, 1203 (QB 1839).

${ }^{132} 2$ Works of James Wilson at 38 (cited in note 3 ).

13 s 4 Mass 1, 27 (1808).

134 Id.

138 Id. 
suggests that because the right is the people's, only they can waive it. Immunity for legislative acts is a necessary freedom that is bound to the concept of genuine representation. It follows that the source of this immunity is the people who have chosen to have representative government. Only they can alter the nature of their voice in government through the lawful process by which changes in government are effected. At the federal level, change in the form of representation can be made by amendment to the Constitution; at the state level, each state likewise has a lawful mechanism for changing the form of government. At the municipal level, state or local charters may give the people a method of changing the form of representation perhaps by referendum or through action by their state representatives. ${ }^{138}$ In any case, lawful means to effect change in government exist, and any diminution of the freedom of representative government must be made by the people-not the courts-through lawful means.

Legislative immunity is not only a right of the people, it becomes a right of each individual legislator when he or she takes on the responsibility of representation. A legislator acts under the presumption that he or she speaks for the people. The representative should be able to take for granted the immunity that the privilege is designed to protect. If the people lawfully alter the form of representative government by diminishing or abrogating the immunity, the legislator loses not only the freedom to make law in an unimpeded manner, he or she also loses an essential part of the role of legislator. The legislator is then on notice that he or she is in effect not free to legislate. On the other hand, when a legislator acts under the lawful protection of the privilege (e.g., by voting or debating), even the people cannot strip him or her of the lawful immunity for actions already taken.

A court should not be able to take away the legislative privilege without the authority of the people and a specific waiver by every affected legislator. A court nevertheless retains the ability to compel a city as a body to execute the law. Although a federal judge may perform quasi-legislative or extra-judicial functions when such powers have been specifically delegated, there are limits to this power. ${ }^{137}$ Courts may not assume the legislative role. As in Yonkers, ${ }^{138}$ local legislators might well insist that a judge enact the

136 Note that in Yonkers there was a state mechanism in place to remove power from the council if it became necessary. Yonkers, 856 F2d at 458.

${ }^{137}$ Mistretta v U.S., $109 \mathrm{~S}$ Ct 647, 658-67 (1989).

138 Yonkers, 856 F2d at 451. 
unpopular legislation, so that the blame will rest on the judge rather than on the legislator. A judge can neatly sidestep this trap by trying to coax the parties into an agreed upon compromise, called a consent decree.

\section{Consent Decrees}

This comment has suggested that legislative immunity cannot be waived except by the people through a fundamental restructuring of the form of government. It is equally doubtful that an individual legislator or a group of legislators can waive the immunity through accession to a consent decree. The nature of consent decrees and their effect on the parties to agreements, as well as on third parties, demonstrate that legislators at all levels who have the common law privilege cannot be coerced by the enforcement of a consent decree. The comment will analyze three facets of the consent decree issue: the authority of legislators to enter into a decree waiving immunity, the legality of such a waiver, and the effectiveness of consent decrees in resolving disputes.

A consent decree is like a contract: the parties who give consent must first have the authority to do so, and, second, they must make a lawful agreement. In Local Number 93, International Association of Firefighters $v$ City of Cleveland, ${ }^{139}$ the Supreme Court upheld a consent decree even though its scope exceeded the remedy that could have been awarded under statutory authority had the case been tried. ${ }^{140}$ The Court stated that consent decrees have a "dual character": they are both contracts and judgments. ${ }^{141}$ Whereas the decree has the force of a judgment, the authority of the court to enforce the consent decree emanates from the contractual agreement of the parties. ${ }^{142}$ Justice Brennan explained that it is "the agreement of the parties, rather than the force of law upon which the complaint was originally based, that creates the obligations embodied in a consent decree,"143 but that these obligations may not conflict with or violate the law. ${ }^{144}$ These two issues-the authority of parties to enter into a contract and the lawfulness of the decree-are central to understanding the municipal legislator's

1s9 478 US 501 (1986).

140 Id at 528. The only question raised and addressed was whether the consent decree was prohibited by the federal statute (Title VII of the Civil Rights Act of 1964) upon which the original suit was brought. Id at 514.

141 Id at 519.

142 Id at 522 .

14 Id.

14 Id at 526. 
privileges in an agreement between a city and another party.

\section{A. The Authority of the Parties to Enter into the Agreement}

Consent decrees, like contracts, must be agreed upon by all parties in order to bind them. ${ }^{145}$ Only through the force of the agreement does the judge have the authority to enforce the consent decree. This power depends on the nature of the consent decree as a contract. Judge Frank Easterbrook has said:

To take seriously the proposition that the decree depends on consent is to require the court to ask whether the consent is authoritative .... The logical question is whether a person making a contractual undertaking to settle a case has the authority to enter into the contract. If he does, the consent is effective. If he does not, the noncontract does not get any additional force by being filed with a court. ${ }^{146}$

Parties to a consent decree that purports to bind local legislators include a plaintiff (perhaps the federal government or a private party) and a local governmental body. As we have seen, neither of these parties has the authority to waive or abrogate the immunity of an individual legislator. When a consent decree attempts to waive this immunity it is not "authoritative" and is a "noncontract."

$\mathrm{J}_{\text {i1 }}$ order to waive legislative immunity, therefore, the party who waives it must have the authority to do so. The existence of a consent decree does not obviate the need for proper authority. Even in instances where the immunity is unaffected by the consent decree, it seems unlikely that legislators have the authority to "bargain away" their power to vote for legislation. ${ }^{147}$ To avoid the problem of binding legislators, local government consent decrees should only contain agreements to execute (e.g., to build a certain number of buildings), and not agreements to legislate (e.g., to pass a law that would enact building proposals). ${ }^{148}$ Agreements to exe-

245 Id at 529.

${ }^{146}$ Frank H. Easterbrook, Justice and Contract in Consent Judgments, $1987 \mathrm{U}$ Chi Legal F 19, 35.

${ }^{147}$ See Jeremy A. Rabkin and Neal E. Devins, Averting Government by Consent Decree: Constitutional Limits on the Enforcement of Settlements with the Federal Government, 40 Stan L Rev 203, 213-214 (1987), explaining that legislatures cannot "bargain away" sovereign powers (citations omitted).

${ }^{103}$ But see id at 228-242, asserting that not all executive authority can be bargained away. See generally Michael W. McConnell, Why Hold Elections? Using Consent Decrees to Insulate Policies From Political Change, 1987 U Chi Legal F 295. 
cute do not need to include legislative promises, and hence do not affect the privilege of a legislator to vote. In mixed forms of government, such as a city council that performs both executive and legislative functions, the local body could agree to perform executive tasks. If the city fails to comply, the judge could enforce the judgment against it and against any individual who fails to carry out an executive duty. In this way, a judge could order action (either from a litigated judgment or from a consent decree) without affecting the freedom of legislators to speak and deliberate about issues. Whereas consent decrees to legislate may be short cuts to the execution of a plan, they ignore the legislative immunities and lawful mechanisms that intervene.

\section{B. A Consent Decree Must Not Violate the Law}

A federal court has the power to enforce a consent decree, yet this power only exists "to the extent that [the agreement] is not otherwise shown to be unlawful. . . "149 Because the consent decree "is an exercise of federal power, enforceable by contempt," the court must ensure that "the decree is consistent with the Constitution and laws, does not undermine the rightful interests of third parties, and is an appropriate commitment of the court's limited resources."180 The court must "scrutin[ize]" the consent decree to ensure that it is "fair, adequate, and reasonable."151

The threshold issue, therefore, is whether the consent decree violates the law. One aspect of this problem is whether the parties had authority to waive legislative immunity. In Kasper $v B d$. of Election Com'rs of City of Chicago, the Seventh Circuit noted that "[s]ome rules of law are designed to limit the authority of public officeholders, to make them return to other branches of government or to the voters for permission to engage in certain acts."152 Legislative immunity is just such a rule of law. None of the parties has the right to make such an agreement; only the people can waive the public right of legislative immunity. A consent decree that contains an agreement to legislate is unlawful because it binds each individual legislator to vote a certain way. Not only does it

${ }^{149}$ Local Number 93, 478 US at 523, 526.

${ }^{260}$ Kasper $v$ Bd. of Election Com'rs of City of Chicago, 814 F2d 332, 338 (7th Cir 1987).

${ }^{181}$ Ibarra o Texas Employment Commission, 823 F2d 873, 878 (5th Cir 1987). The court used Texas contract law to invalidate the decree on account of "mistake." Id at 879.

152814 F2d at 341, quoting Dunn v Carey, 808 F2d 555, 560 (7th Cir 1986). Kasper differs from Yonkers in that the consent decree involved circumvention of explicit statutory requirements, rather than common law. 
require an action that only the people and the individual legislator's conscience should compel, but it allows a court to impose liability upon any legislator who refuses to vote according to the dictates of the decree.

As part of the analysis of the lawfulness of a decree, a court must also consider the legal effect of the decree on third parties. As a type of judgment, a consent decree is binding on all parties, but like a settlement, it cannot settle any claims of or "impose duties or obligations on a third party, without that party's agreement." "15s In the Yonkers case, the city agreed to the consent decree, and the councilmen voted to approve the decree by a majority vote. ${ }^{154}$ The councilmen, however, were not parties to the decree. One councilman voted against approval of the consent decree and subsequently against the legislation to enact the housing plan. ${ }^{155}$ Even though he had never voted for any of the agreements, the councilman was found in contempt for not legislating pursuant to the decree. ${ }^{156}$ Evidently, the court decided that there was no distinction between the city and any of the councilmen. ${ }^{157}$

The identification of councilmembers as parties separate from their city seems necessary if a judge intends to single them out as targets for coercive enforcement. The interests of each municipal legislator, after all, are not identical to those of a city. His or her constituency may hold opinions that differ from those of the body as a whole. In a consent decree between a city and another party, therefore, an individual councilman is better characterized as a third party rather than as an alter-ego of the city.

If a legislator is bound as an individual, is the consent decree lawful? The decree is understood as a contract, and its legality depends on terms that are acceptable to all parties, including the individual councilmen. If the city alone represents the interests of the municipality, then a judge can enforce the judgment only against the city. ${ }^{158}$ If, on the other hand, both the city and the individual legislators are parties, then it seems that all must consent to the decree before it is effective against all of them. ${ }^{159}$ Only

1ss Local Number 93, 478 US at 529.

154 856 F2d at 448; McFadden, NY Times 36 (Sept 11, 1988) (cited in note 6).

Iss 856 F2d at 457.

186 Id.

157 Spallone, $109 \mathrm{~S} \mathrm{Ct}$ at $16,17$.

138 "[O]nly the parties to the decree can be held in contempt of court for failure to comply with its terms." Local Number 93, 478 US at 530, citing United States $v$ Armour \& Co., 402 US 673, 676-677 (1971).

130 "[O]f course, a court may not enter a consent decree that imposes obligations on a 
when the individual legislators are named as parties should the judge have the authority to enforce the decree against them individually. ${ }^{160}$ Municipal legislators, as separate parties who are purportedly bound by a decree, may intervene and assert their own and the people's common law rights. They could then ask the court to judge the validity of their immunity or to modify the consent decree to specifically protect their privilege. ${ }^{101}$

Even though the legislators could intervene in a case to protect their privileges, their lack of intervention does not prevent them from asserting their rights in a different action. In Martin $v$ Wilks the Court recently held that nonparties to a consent decree cannot be barred from collaterally attacking the decree. ${ }^{162}$ In Martin, the parties to the underlying suit had agreed to consent decrees that provided for hiring and promotion goals to correct past discrimination in the Birmingham, Alabama, fire department. ${ }^{163} \mathrm{~A}$ group of white firefighters sued the city and the county personnel board in federal court. They alleged that they were being "denied promotions in favor of less qualified blacks in violation of federal law."184 The District Court dismissed their claim on the basis that third parties could not challenge the consent decrees that mandated the promotion plan. The Eleventh Circuit reversed and held that the white firefighters could not be barred from attacking the decree since they were not parties to its formation. ${ }^{165}$ The Supreme Court affirmed the Eleventh Circuit's opinion and allowed the challenge by the nonparties to the original consent decrees. The Court reasoned: "A voluntary settlement in the form of a consent decree between one group of employees and their employer cannot possibly 'settle,' voluntarily or otherwise, the conflicting claims of another group of employees who do not join in the agreement."188

If the court in Yonkers was correct in holding that the consent decree bound the legislators, the liability of the individual council-

party that did not consent to the decree." Local Number 93, 478 US at 530 (citations omitted).

${ }^{180}$ See id at 529. Parties "may not impose duties or obligations on a third party, without that party's agreement."

${ }^{161}$ A third party "does not have power to block the decree merely by withholding its consent," but the consent decree "cannot dispose of the valid claims of nonconsenting intervenors." Id.

${ }^{162} 109$ S Ct 2180, 2183, 2188 (1989).

163 Id at 2183.

104 Id.

${ }^{203}$ In re Birmingham Reverse Discrimination Employment Litigation, 833 F2d 1492, 1498-1500 (11th Cir 1987).

${ }^{188} 109 \mathrm{~S}$ Ct at 2188. 
men was entirely foreseeable. This predictability might require that the councilmen be joined as parties to the action. ${ }^{167}$ Douglas Laycock argues that "courts should not enter consent decrees without the consent of all the foreseeable parties whose arguable legal rights are directly affected."168 If the courts fail to join these foreseeable parties, however, the decree has no effect on them, because "[i]t is simply beyond the power of the court" to bind them. ${ }^{169}$ The Court in Martin made it clear that the presence of a consent decree does not mandate the intervention by third parties: "Joinder as a party, rather than knowledge of a lawsuit and an opportunity to intervene, is the method by which potential parties are subjected to the jurisdiction of the court and bound by a judgment or decree."170 The councilmen in Yonkers were bound by the consent decree at the very least when they were held in contempt for noncompliance. ${ }^{171}$ Following Martin they "cannot be deprived of [their] legal rights in a proceeding to which" they were not parties. ${ }^{172}$ Furthermore, even if they failed to intervene in the original suit, they did not lose their right to challenge the decree. ${ }^{173}$

\section{Consent Decrees that Abrogate Legislative Immunity are Un-} lawful and Without Authority, Hence Ineffective

If a judge approves an agreement to legislate and the legislator refuses to comply, the resulting enforcement through contempt effectively is a coercion to legislate. Consequently, when a judge enforces the consent decree against a municipal legislator, that legislator may be able to challenge the consent decree directly. ${ }^{174}$ The court then should either find that the privilege of the legislator

${ }^{107}$ Id at 2186. See also Douglas Laycock, Consent Decrees Without Consent: The Rights of Nonconsenting Third Parties 1987 U Chi Legal F 103, 129 (proposes joinder if third party is foreseeable).

168 Id at 154.

189 Id at 104, 112-128. See Local Number 93, 478 US at 529; Firefighters $v$ Stotts, 467 US 561, 588 and n 3 (1984) ( $0^{\prime}$ Connor concurring), stating that if a party is "required to make any sacrifices in the final consent decree, [it] must be represented and have had full participation rights in the negotiation process."

170 Martin, $109 \mathrm{~S} \mathrm{Ct}$ at 2186.

171 The Second Circuit stated that the Yonkers City Council became bound when it "approved the terms of the Consent Judgment" by a vote in the council. The court also held that even the member who did not vote for the measure was bound. Yonkers, 856 F2d at 457.

${ }^{172}$ Martin, $109 \mathrm{~S} \mathrm{Ct}$ at 2183.

173 Id at $2185-86$.

${ }^{174}$ Id. See also Local Number 93, 478 US at 529; Larry Kramer, Consent Decrees and the Rights of Third Parties, 87 Mich L Rev 321, 331-332 (1988), advocating that a party should be able to intervene. 
must be protected pursuant to the common law or that the legislator is not bound by the decree since he or she was not a party to the agreement. ${ }^{175}$

A municipal legislator should not have to wait until the threat of contempt is imminent. Uncertainty of liability would have a chilling effect on legislation. A councilmember would have to live and work with the knowledge that his or her right to legislate freely would be challenged if the judge's decree failed to achieve a majority vote in the council. Rather than cast a tenuous vote, a councilmember contemplating a vote against a measure advocated by a consent decree would probably prefer to intervene in the federal court prior to the imposition of the decree. The Yonkers case, moreover, makes the threat of action against a legislator more likely. After Yonkers, a councilmember has to worry that if he or she fails to assert this right-if perchance a majority of the council decides to vote against the judicially ordered legislation-he or she could face a contempt judgment. A legislator should, therefore, challenge any agreement that includes a promise to legislate. The mere presence of a consent decree does not prevent a challenge and does not abrogate the right of the legislator to vote freely.

If consent decrees are to continue as an effective method of resolution, a judge must ensure that those involving cities do not purport to waive the immunity of local legislators. If legislative privilege is not protected, the decree is unlawful, and the federal judge has no authority over the councilmembers. Congress has not waived the common law protection, ${ }^{178}$ and the council as a whole cannot independently waive its immunity. ${ }^{177}$ In short, a court should not approve a consent decree that brings the basic freedom of the legislative process under the coercive powers of the judiciary.

\section{Conclusion}

The history of legislative immunity reveals its purpose: to guarantee a free representative form of government by assuring free deliberation and accountability. The people as the sovereign authority for the government possess the right of free speech or debate for their elected. voice in government. They retain this right, and neither the legislator nor the representative body can

176 Martin, $109 \mathrm{~S}$ Ct at 2188, citing Local Number 93, 478 US at 529.

${ }^{178}$ Consumers Union, 446 US 719, 732, 738 (1980).

177 See text accompanying notes 131-34. 
waive it without the consent of the people. Even the slightest waiver of legislative immunity constitutes an alteration of the form of government chosen by the people, for a government that forces representatives to vote a certain way transforms the legislative process into an executive function.

If legislative immunity can be waived at all, it must be done through the process by which lawful change in the form of government can be made. In the case of municipalities, states may have the authority to alter the form of local government. Congress may also have this authority, but it has never shown any intent to abrogate the common law immunity. If any party abrogates the privilege, the representative nature of the lawmaking power is diminished.

Even if Congress has the power to order an individual city councilmember to vote for legislation, it should not use this power lightly, because it may violate the common law rights of the individuals and of the people. There are, after all, other means to exact the same result from a government body without denying the immunity. Once the fines against the councilmen were abated in Yonkers, the action taken against the city worked, ${ }^{178}$ as it has in all other like cases.

A consent decree cannot alter the privilege of legislators. In order for the decree to have the lawful power to abrogate the immunity of municipal councilmembers, one of the parties to the decree must have the right to waive the privilege. The Yonkers court did not decide whether the parties had the authority to waive the immunity, but rather assumed that the consent decree effected a waiver. ${ }^{179}$ When the privilege is threatened, individual legislators have the right to challenge such a decree and to assert that it is unlawful. If a court decides that a decree does not purport to waive legislative privilege, it may still coerce the governmental body to execute the decree. It can force a city-but not the legislators-to act. If on the other hand a court finds that the decree attempts to waive legislative immunity, it should find that the decree is without authority and must not be enforced."

Courts that abrogate the immunity of local legislators threaten the legislative process. Even in the guise of enacting beneficial leg-

178 McFadden, NY Times 36 (Sept 11, 1988) (cited in note 6).

179 The Second Circuit stated, "[e]ven if we assume ... that city council members enjoy the same immunity available to state legislators, we would seriously doubt that such immunity insulates them from district court orders requiring them to comply with remedial decrees ...." Yonkers, 856 F2d at 456. 
islation, any court's intrusion into the deliberative process of a legislative body is undesirable. The essential values of our representative form of government are seriously challenged when a judge holds the spokespersons in government personally liable for their speech or debate-the "ancient privilege" of the people. 